Environment Conservation Journal 15(1 \& 2) 149-152, 2014

ISSN 0972-3099 (Print) 2278-5124 (Online)

Abstracted and Indexed

\title{
Development of primary cell culture from the caudal fin region of snow trout Schizothorax plagiostomus (Heckel)
}

\author{
Ashish K. Chowdhary and S N Bahuguna $\bowtie$
}

Received: 02.12.2013

Revised: 28.04.2014

Accepted: 02.05.2014

\begin{abstract}
A primary cell culture has been established from the Snow trout Schizothorax plagiostomus. Primary cultures have developed from caudal fin tissues by explant culture technique. Cell outgrowth has been obtained from the caudal fin explant after 5-7 days of explant culture. The culture medium used for the experiment was Leibovitz-15 supplemented with $20 \%$ Fetal Bovine Serum. Radiation of cells from the explants started after 2 to 3 days. Both fibroblast like and epithelial like cells were noticed but fibroblast like cells dominated as the growth progressed.
\end{abstract}

Keywords: explant technique, fetal bovine serum, leibovitz-15media, primary cell culture, Schizothorax plagiostomus

\section{Introduction}

The subfamily Schizothoracinae (Family: Cyprinidae), which includes snow trout Schizothorax (spp) and several other genera important for fisheries, is available in the Himalayan and sub-Himalayan regions of the Indian subcontinent, Afghanistan, Central Asia, Kazakhstan, China and Myanmar. Schizothoracines inhabit cold waters up to the altitude of $3,323 \mathrm{~m}$, being present in rivers, streams and lakes, prefer temperature in the range of $8-22^{\circ} \mathrm{C}$. Most of these fish are valued by the local people for their size and food value. Fish culture at high altitudes has the potential to produce food for people using proven technologies in addition to the potential of ecotourism. The availability of breeding and fish farming technologies makes it possible to practice fish culture for a number of exotic and indigenous coldwater fish species in the Indian Himalayas. The most important cultivable coldwater species include Neolissoceillis hexagonolepis, Puntius (Tor) chelynoides, T. putitora, T. tor among the mahseers, Schizothorax richardsonii, Schizothorax plagiostomous and Schizothoraichthys progastus among the snowtrout (Singh et al., 1993). Only a few cell lines have been developed from warm

\section{Author's Address}

Department of Zoology and Biotechnology, P.B.70, HNB

Garhwal University Srinagar, Uttarakhand, India

Email: profsnbahuguna@ rediffmail.com water fish species such as catfish and from coldwater fish species such as snow trouts and mahseers (Lakra et al., 2006, Goswami et al., 2012). Although there are about 11 reports on cell cultures from indigenous fish of India, information on their utilization and availability is lacking when in vitro studies related to fish virology and transgenesis require cell lines from Indian fish (Lakra et al., 2006). A fibroblast like cell line was established from Tor putitora by Lakra et al., (2006) and Tor chelynoides by Goswami et al., (2012) in India. No further work has been done on the development of cell lines from other coldwater fishes. Fish cell lines are finding increasing applications in fish toxicology, carcinogenesis and evaluation of immune responses etc. Lymphocystis virus disease, nodavirus, iridovirus, spring viremia of carp virus etc. are the most devastating and causing mortalities in marine and freshwater fish. Due to the lack of suitable cell lines, little is known about the epidemiology of viral infections and characterization of the virus in Indian fishes, mostly coldwater fishes such as snowtrout (Chi et al., 1999; Chen et al., 2005).

\section{Material and Methods}

Since Schizothorax plagiostomus is a cold water fish, conditions were optimized carefully for their culture. It was found that $26-28^{\circ} \mathrm{C}$ is ideal 
temperature of incubation for their cell growth. For setting up the primary cultures, the fry and fingerlings were selected and initially kept in aerated distilled water to remove some micro organisms adhered to its body surface and then was sacrificed and the surface was disinfected using sodium hypochlorite solution (500 ppm available chlorine) for $5 \mathrm{~min}$ followed by a thorough rinse with sterile double glass distilled water. The caudal fin was aseptically excised from fingerlings and rinsed individually with phosphate-buffer saline (PBS) (Himedia) and with antibiotic and antimycotic. Explants of $1 \mathrm{~mm}^{3}$ size were prepared by chopping them with scissors in small petridishes inside the sterile laminar airflow hood. The explants were seeded in $25 \mathrm{~cm}^{2}$ tissue culture flask (Grenor Bio-One) and kept semi dry for 16-20 hours at $28{ }^{\circ} \mathrm{C}$. The adherence of explants was accomplished by incubation with $0.5 \mathrm{ml}$ of Fetal Bovine Serum at $28^{\circ} \mathrm{C}$. After that the growth medium L-15 (Himedia) was added gently which was kept at $4{ }^{\circ} \mathrm{C}$. The media added contained the Media serum ratio of $4: 1$. Fifty percent of the media will be exchanged once in every 3 days. Daily observations were made using an inverted microscope (Nikon Eclipse TS100) and photo micrographs were taken regularly for the cell line developmental study.

\section{Results and Discussion}

Attachment, cell outgrowth and proliferation of cells by explant culture is achieved. Radiation of cells from the explants started after 2 to 3 days in $25 \mathrm{~cm}^{2}$ tissue culture flasks from caudal fin explants and cells formed confluent monolayer within 5 to 7 days. The flasks were observed daily for attachment of explants, spreading and proliferation of cells, morphological details using an inverted microscope. During the initial stages of culture, both fibroblast like and epithelial like cells were noticed but fibroblast like cells dominated as the growth progressed (Fig.1).

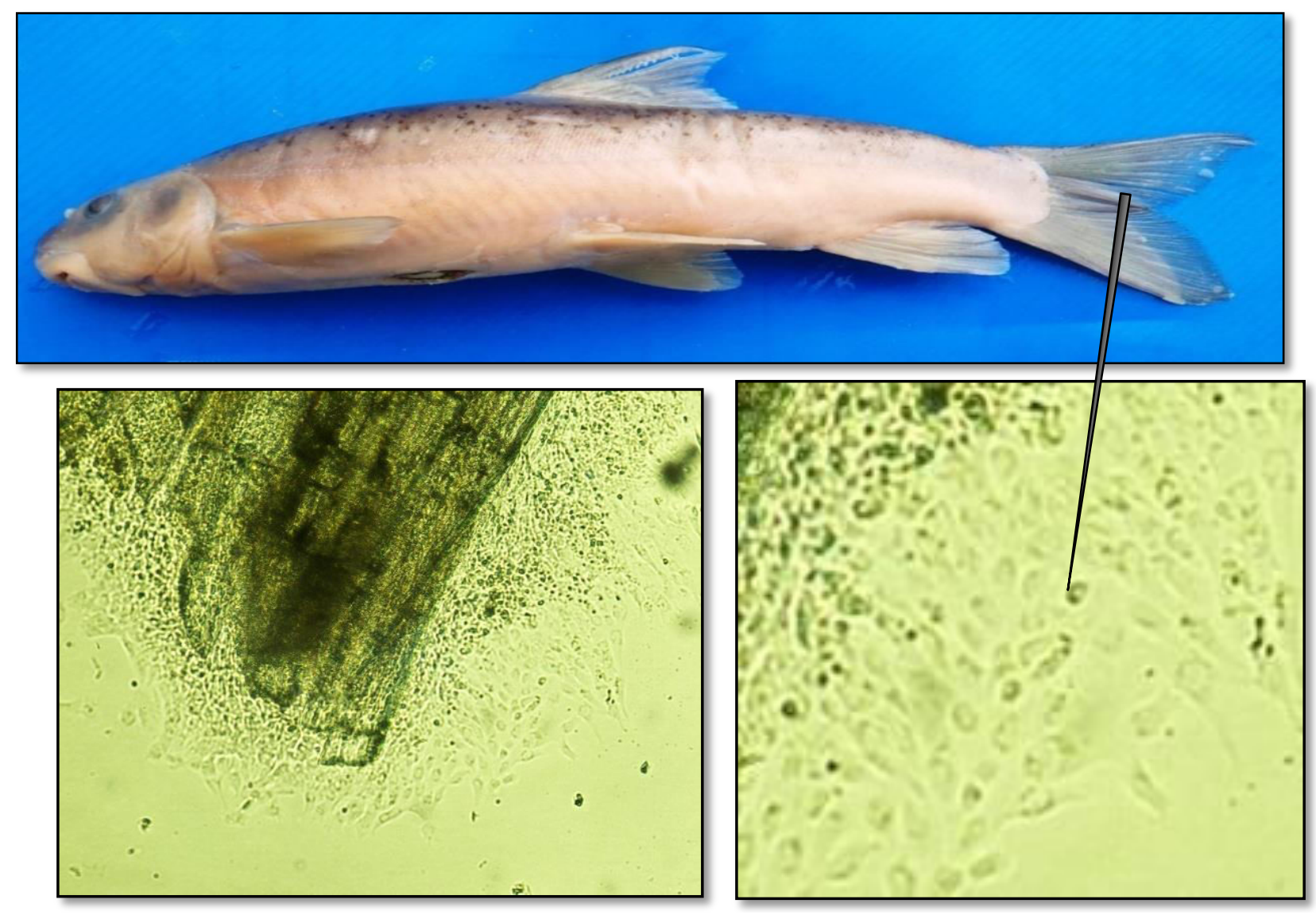

Fig 1: Radiation of cells from the explants of sample fish Schizothorax plagiostomus (Heckel) 
Cell cultures can vary greatly in their sensitivities to different viruses. If a virus is inoculated into an insensitive cell culture, the virus will not be able to replicate and a negative result will be obtained. When small amount of virus are present in a specimen such as an early viral infection, a positive result may be obtained only when the most sensitive cell culture system is used. Therefore, successful establishment of cell lines from various fish economically important to Indian aquaculture will improve diagnosis of viral disease and prevention. The research needs in fish pathology and health management have immediate relevance to aquaculture especially in the inland fisheries in which coldwater fisheries is one of the important sub sectors. Biotechnological interventions to combat the bottlenecks in cold water fisheries development are very relevant to increase fish production and conserve biodiversity. In India, there has been quite a progress towards the development of cell lines from Indian major carps and other warm water fishes (Singh et al., 1993; Lakra and Bhonde, 1996; Rao et al., 1997; Kumar et al., 1998; Prassanna et al., 2000; Kumar et al., 2001). A few cell lines MG-3 (Sathe et al., 1995) and RG-I and RG-2 (Sathe et al., 1997) derived from gills of Cirrhinus mrigala and Labeo rohita, respectively have been established and characterized. Most recently, new cell lines have been developed from Tor putitora (Lakra et al., 2006), Lates calcarifer (Lakra et al., 2006 and Hameed et al., 2006), embryonic cell line from Lates calcarifer by Parameswaran et al., 2006 and Puntius (Tor) Chelynoides by Goswami et al. (2012). Although a large number of fish cell lines ( 159) have been established for isolating and identifying fish viruses (Fryer \& Lannan 1994), relatively few marine fish cell lines $(\sim 34)$ are available (Chi et al. 1999). Development of embryonic cell lines has been carried out in number of marine fishes such as LJES I from sea perch, Lateolabra japonicus (Chen et al., 2003a), FEC from Japanese flounder Paralichthys olivaceus (Chen et al., 2004) and TEC from turbot Scophthalmus maximus (Chen et al., 2005).

In India, there have been few attempts towards the development of cell lines from Indian major carps and other warm water fishes. However, there is no information on the availability of cell lines of coldwater fishes except Tor putitora by Lakra et al. 2006 and Tor chelynoides by Goswami et al., 2012, in India. Hence, there is an urgent need to develop cell lines from coldwater fish species of aquaculture importance.

\section{Acknowledgement}

The authors are highly grateful to Department of Biotechnology (DBT) for financial assistance (Project sanction No. BT/PR11721/AAQ/03/452/

2008) and to the Head Department of Zoology and Biotechnology, HNB Garhwal University for providing laboratory facilities during the work.

\section{References}

Chen, S.L., Sha Z. X., and Ye, H.Q. 2003a. Establishment of a pluripotent embryonic cell line from sea perch blastula embryo. Aquaculture 218:141-151.

Chen, S.L., Ren, G.C., Sha, Z.X. and Shi, C.Y. 2004. Establishment of a continuous embryonic line from flounder Paralichthys olivaceus for virus isolation. Dis. Aquat. Org. 60: 241-246

Chen, S.L., Ren, G.C., Sha, Z.X. and Hong, Y. 2005. Development and characterization of a continuous embryonic cell line from turbot Scophthalmus maximus. Aquaculture 249: 63-68.

Chi, S.C., Hu, W.W. and Lo, B.J. 1999. Establishment and characterization of a continuous cell line (GF-1) derivered from grouper Ephinephelus coioides (Hamilton): a cell line susceptible to grouper nervous necrosis virus (GNNV). J. Fish Dis. 22:173-182.

Fryer, J.L. and Lannan, C.N. 1994. Three decades of fish cell culture: a current listing of cell lines derived from fishes. Journal of Tissue Culture Methods 10:57-94.

Goswami, M., Sharma, B.S., Tripathi, A.K., Yadav, K., Bahuguna, S.N., Nagpure, N.S., Lakra, W.S., Jena, J.K. 2012. Development and characterization of cell culture systems from Puntius (Tor) chelynoides (McClelland). Gene 500(1): 140-147.

Hameed, A.S. Sahul, Parameswaran, V., Shukla, R., Singh, I.S. Bright, Thirunavukkarasu, A.R. and Bhonde, R.R. 2006. Establishment and characterization of India's first marine fish cell line (SISK) from the kidney of sea bass Lates calcarifer. Aquaculture 257 (1-4): 92-103.

Kumar, G.S., I.B.S. Singh and R. Philip 1998. Efficacy of fish and prawn muscle extracts as supplements of medium in development of primary cell culture system from larval tissue of aquarium fish, Poecilia reticulata. Indian $\mathbf{J}$. Exp. Biol. 36: 91-94. 
Kumar, G.S., I.B.S. Singh and R. Philip 2001. Development of a cell culture system from the ovarian tissue of African catfish (Clarias gariepinus). Aquaculture 194: 51-62.

Lakra, W.S., Bhonde, R.R. 1996. Development of primary cell culture from the caudal fin of an Indian major carp, Labeo rohita (Ham.). Asian Fish Sci. 9:149-152.

Lakra, W.S., Bhonde, R.R., Sivakumar, N., Ayyappan, S. 2006. A new fibroblast like cell line from the fry of golden mahseer Tor putitora (Ham). Aquaculture 253(1-4): 238243.

Lakra, W.S., Sivakumar, N., Goswami, M., Bhonde, R.R. 2006. Development of two cell culture systems from Asian seabass Lates calcerifer (Bloch). Aquacult Res. $37: 18-24$.
Rao, K.S., Joseph, M.A., Shanker, K.M., Mohan, C.V. 1997. Primary cell culture from explants of heart tissue of Indian Major Carps. Curr. Sci. 73: 374-375.

Singh, N., Bahuguna S.N., Bhatt, K.C. 1993. The profile of river ecosystem, food and feeding habits of Hill-stream fishes and consequences of recent environmental degradation in garhwal Himalaya. Acta Ichthylologica, Vol.XXIII.

Sathe, P.S., Maurya, D.T., Basu, A., Gogate, S.S., Banerjee, K. 1995. Establishment and characterization of a new fish cell line, MG-3, from the gills of Mrigal Cirrhinus mrigala. Indian J. Exp. Biol. 33: 589-594.

Sathe, P.S., Basu, A., Mourya, D.T., Marathe, B.A., Gogate, S.S. and Banerjee, K. 1997. A cell line from the gill tissues of Indian cyprinoid, Labeo rohita. In Vitro Cell Dev. Biol. Anim. 33 (6): 425-427. 